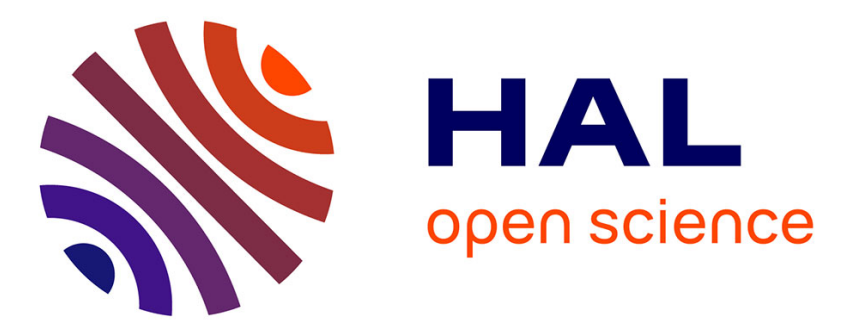

\title{
Growth and cellular differentiation: a physical-biochemical conundrum? The example of the hand
}

Laurent H Schwartz, Habibou Maitournam, C. Stolz, J. M. Steayert, Marie-Christine Ho Ba Tho, Bernard Halphen

\section{To cite this version:}

Laurent H Schwartz, Habibou Maitournam, C. Stolz, J. M. Steayert, Marie-Christine Ho Ba Tho, et al.. Growth and cellular differentiation: a physical-biochemical conundrum? The example of the hand. Medical Hypotheses, 2003, 61, pp.45-51. 10.1016/S0306-9877(03)00102-6 . hal-00111386

\section{HAL Id: hal-00111386 \\ https://hal.science/hal-00111386}

Submitted on 1 Aug 2019

HAL is a multi-disciplinary open access archive for the deposit and dissemination of scientific research documents, whether they are published or not. The documents may come from teaching and research institutions in France or abroad, or from public or private research centers.
L'archive ouverte pluridisciplinaire HAL, est destinée au dépôt et à la diffusion de documents scientifiques de niveau recherche, publiés ou non, émanant des établissements d'enseignement et de recherche français ou étrangers, des laboratoires publics ou privés. 


\title{
Growth and cellular differentiation: a physico- biochemical conundrum?The example of the hand
}

\author{
L. Schwartz, ${ }^{1}$ H. Maitournam, ${ }^{2}$ C. Stolz, ${ }^{2}$ J. M. Steayert, ${ }^{3}$ M. C. Ho Ba Tho, ${ }^{4}$ B. Halphen ${ }^{2}$ \\ ${ }^{1}$ Service de Radiotherapie, Hôpital Pitié-Salpétrière, Boulevard de l'Hôpital, Paris Cedex, France; ${ }^{2}$ Laboratoire de Mécanique des Solides, Ecole \\ Polytechnique, Palaiseau, France; ${ }^{3}$ Laboratoire d'informatique, Ecole Polytechnique, Palaiseau, France; ${ }^{4}$ Biomécanique, Compiègne 60205 , France
}

Summary Currently, the predominant hypothesis explains cellular differentiation as an essentially genetic intracellular process. The goal of this paper is to suggest that cell growth and differentiation may be, simply, the result of physical and chemical constraints. Bone growth occurs at the level of cartilage conjunction (growth plate) in a zone of lesser constrain. It appears that this growth also induces muscle, tendon, nerve and skin elongation. This cartilage growth by itself seems to explain the elongation of the hand. Growth stops at puberty likely because of feed-back from an increasing muscle load. The ossification (that is differentiation of cartilage into bone) appears to result from the shear stress induced. The study of bone age, obtained by X-ray picture of the hand, shows that ossification of epiphyses is very precise both in time and space. Computer modelization suggests that this ossification occurs where shear stress is greatest. The cartilage which does not ossify (joint, nose, larynx, ear, bronchus, etc.) is not exposed to high shear. Shear stress induces the secretion of extracellular matrix and a change of the biochemical environment of the cell. Precipitation of calcium phosphate, as in ossification, seems related to the alkalosis induced by shear stress. To speak in more general terms, loss of cellular differentiation, as occurs with cancer, can result from a change in the physical-chemical environments.

\section{INTRODUCTION}

The growth and maturation of the hand is a highly predictable phenomena (1). During embryogenesis, bones of the diaphysis are formed on an initial cartilaginous model. Cartilage is later replaced by bone; this process is called enchondral ossification (2). The long bones of the hand end near the joint in a separate epiphysis, which is ossified during childhood. The epiphysis becomes fused with the shaft of the bone (diaphysis) at puberty when growth comes to an end (2). The epiphyses undergo a

Correspondence to: Dr. L. Schwartz MD, Service de Radiotherapie, Hôpital Pitié-Salpétrière, 47 Boulevard de l'Hôpital, Paris Cedex 13 75651, France.; E-mail: laurent.schwartz@polytechnique.fr characteristic series of events: central calcification, $a b-$ sorption of cartilage and enchondral ossification (2). At birth, there is no limited detectable bone on X-ray of the epiphysis of the hand. Bone development assessed by a simple radiological picture of the right hand has been used to confirm the age of the infant (1), assess its nutritional status if there is a delay in ossification because of an underlying disease (3) or even estimate the age of the cadaver of an immature child (4).

\section{COORDINATE DEVELOPMENT OF THE HAND}

The proper development of the musculoskeletal system requires the coordinated development of cartilage, bone, muscle, tendon and cartilage (5). In the embryo, ossification of the cartilaginous anlagen of the metatarsus starts in parallel with active movement of the feet by muscle contraction (6). Mechanical stress resulting from 
muscle contraction seems to guide enchondral ossification patterns $(6-8)$.

Comparison of muscle and tendon reveals that much of their morphogenesis is temporally and spatially closely associated (5). Reciprocal muscle-tendon interactions are necessary for correct muscle-tendon patterning and morphogenesis. Tendon development was examined in muscleless limbs produced by coelomic grafting of early limb buds and muscle development was analyzed in limbs where tendon had been surgically altered (5). Subdivision of muscle masses and segregation of tendon primordia into individual tendons do require reciprocal interactions between muscle and tendon (5).

\section{CARTIlage defects is Responsible OF MULTIPLE MALFORMATIONS}

Achondroplasia is a rare genetic disease. The cartilage shows morphological and biochemical abnormalities caused frequently by the substitution of arginine for glycine of the fibroblast growth factor receptor (9-12). This anomaly of the cartilage is responsible for a skeletal dysplasia. At birth, short stature and squared pelvis are not prominent (12). The deformity increases with age (12) and is not limited to the cartilage but also to the bone, the muscles and the peripheral nerves. To speak in more general terms, when there is bone malformation, muscles and tendons do not develop normally; their development is linked to that of the bones, probably due to changes of constraint on muscles and tendons.

By contrast, muscular dystrophies appear mostly limited to the muscle, neurodegenerative disease to the nerves (13).

\section{GROWTH PLATE ARREST STOPS THE GROWTH OF THE HAND}

The use of rigid fixation for fracture of the extremity is common place (14). Epiphyses plated for a year show increased bone differentiation, premature closure and growth arrest (14). They also have shortened muscles, tendons and nerves. In young cancer patients, growth plate injury often results from surgery or radiation therapy. This translates into marked deformity, sclerotic metaphysal bands, muscular atrophy and growth arrest (15). Here again, the muscles, tendons and nerves are shortened. Similar treatments delivered sparing the growth plate have markedly fewer side effects (15).

It is at puberty that growth plates are fused and growth stops. This may be due to a direct hormonal effect. But the normal growth plates are under increased pressure; the largest load comes from muscle (16). The muscle load increases around puberty. The most intense force development occurs between 12 and 15 years of age in boys, and earlier in girls (17). Girls stop growing earlier than boys do. Treatment with testosterone of young boys prior to puberty increases muscle mass, induces puberty and induces growth cessation (18). Similarly, heavily trained gymnasts (19) or swimmers (20) experience attenuated growth during their years of training followed by catch-up growth during reduced training schedule or the months following retirement.

\section{GROWTH PLATE GROWTH MAY BE ENOUGH TO EXPLAIN THE EXPANSION OF THE HAND}

Growth of long bones occurs at the growth plate, a cartilage structure that contains three main layers: the resting, proliferative and hypertrophied zones. Growth of long bones occurs at the growth plate, a layer of cartilage that separates the epiphysis from the metaphysis. Growth plates exhibit spatial polarity. Proliferative chondrocytes undergo terminal differentiation when they approach the metaphyseal, but not the epiphyseal, border of the growth plate (21). By contrast, the elongation of the muscles, the tendons, the skin or the nerves appears secondary to bone growth.

Muscle is highly responsive to changes in functional demands. Overload leads to hypertrophy, while decreased load force generation and immobilization with the muscle in the shortened position leads to atrophy (22).

Human tendon is elongated by the application of load at its extremity (23). Mechanical tension increases the number of fibroblasts (24).

Possessing viscous and elastic rheological properties, skin is viscoelastic. Mechanical creep, defined as the elongation of skin with a constant load over time beyond intrinsic extensibility, has been described as the vehicle harnessed for wound closure with intraoperative tissue expansion (25). Prior to a difficult surgery, because of limited skin for wound closure, a skin-stretching device (an inflattable ballon) is inserted under the skin. After incremental traction the skin is elongated, the wound can be closed. The generation of new results from chronic stretching force confirms that biological creep plays a role in skin growth. Similarly, elongation of peripheral nerves increases the length of the nerves (26).

\section{MECHANICAL REGULATION OF CELL PROLIFERATION}

The development of an organ is constrained by internal and external limitations (27). The effect of shear stress on the endothelial cell is the best-studied example. Shear stress is responsible for vascular network formation, the fractal organization of the arterial and venous trees, as well as the unavoidable tropism of arteries towards capillaries and then veins (28). At the cellular level, shear 
stress induces cell proliferation. The endothelium, however, is not unique in responding to external forces; virtually all cells are affected by the mechanical environment (27). For example, mechanical deformation of fetal rat lung cells simulating fetal respiratory movements increases cellular replication (29). Rhythmic deformation also increases intestinal epithelial cell proliferation in a frequency dependent manner (30).

Proliferation is the acknowledged 'default state' of prokaryotes, unicellular eucaryotes or plant cells. The same is found in normal human cells (31). Both, in vivo and in vitro, normal cells stop proliferating because of contact inhibition caused, in part, by mechanical force (32). It is possible that cell proliferation is limited to the cartilage because of lesser physical constraints compared to the bone.

\section{OSSIFICATION APPEARS TO RESULT FROM GROWTH PLATE GROWTH}

In 1911 , Gebhardt $(33,34)$ suggested that the ossification of the chondroepiphysis started at a point where the accumulation of stress was the greatest. The ossification center of the epiphysis is formed by hypertrophied chondrocytes. In a short period of time, calcium phosphate is deposited in the matrix around these cells (34). In vitro, mouse metatarsal are exposed to external load (34). Intermittent ambient hydrostatic pressure increases the calcification (33). There is accelerated osteogenesis in the area of intermittent high shear $(33,35)$.

Recently, Maitournam et al. (36) has reviewed a data bank of X-ray pictures of the hand of children of various ages. Using a finite-element analysis he has shown that the localization and the pattern of growth of ossification takes place in areas of high hydrostatic pressure and shear stress.

The fact that the combination of shear stress and pressure is correlated to mineralization appears to be a general phenomenon. The ossification of the vertebral body starts at its center, where the shear stress is maximum. The early ossification of the diaphysis of the femur takes place at a time when the joints are flatter $(36,37)$ again in an area of high shear. The cartilage which does not ossify (joint, nose, larynx, ear, bronchus, etc.) is not exposed to high shear stress.

\section{MECHANICAL STRESS AND CELLULAR DIFFERENTIATION}

Mesenchymal stem cells are multipotent cells that can be induced to differentiate into a variety of mesenchymal tissues, including bone, cartilage, tendon, fat, bone marrow stroma and muscle (4). Several mesenchymal cells (mechanocytes) e.g. osteoblasts and fibroblasts as well as muscle cells are activated by mechanical strain (38). In the past two decades, it has been well established that many cells are sensitive to mechanical forces and can change their phenotype and surrounding extracellular matrix (ECM) in response to mechanical environment (39). Traction appears to generate condensation and maturation of chondrocytes or feather, scale and hair formation $(28-30,40-43)$.

Chondrocytes are known to sense and respond to the mechanical stimuli by multiple regulatory pathways: upstream signaling transcription, translation, posttranslational modifications and vesicular transport (44). Fluid induced shear causes chondrocytes to elongate and align (45). Chondrocytes respond to shear stress by an increased secretion of extra cellular matrix namely collagen and proteoglycan (44), as well as the modification of metabolism (45). But primary adult bone cells do not appear to respond to fluid-flow induced shear stress in these physiological ranges (46).

External load also plays a critical role in determining muscle mass and its phenotype in myocytes (47). Myocytes have the ability to sense mechanical stretch and convert it into intracellular growth signals, which lead to hypertrophy. Stretch is, by itself, an important mechanical signal for the production of more actin and myosin filaments and the addition of new sarcomeres. This is preceded by upregulation of transcription of the appropriate genes, some of which, such as the myosin isoforms, markedly change muscle phenotype. Indeed, the switch in the expression induced by mechanical activity of myosin heavy chain genes, which encode different molecular motors, is a means via which the tissue adapts to a given type of physical activity (25). Mechanical stretch of myocytes in vitro causes activation of multiple second messenger systems that are very similar to growth factor-induced cell signaling systems.

Similarly, traction induces the secretion of extracellular matrix by fibroblasts, distorts collagen gels and creat patterns similar to tendon (48). This morphogenetic rearrangement of extracellular matrix is the primary function of fibroblast traction and explains its excessive strength (48).

Stem cells may be expanded in culture and subsequently permitted to differentiate into the desired lineage. This directed differentiation might be reached by the application of bioactive molecules, growth factors and signaling molecules (38). It is known that physical stress induces the secretion of these growth factors and signaling molecules (28). The question is whether mechanics alone during normal development are sufficient to explain the growth and differentiation of the tissues. If this hypothesis is proven correct, the next question is whether the effects of mechanical forces are being mediated or mimicked through the release of chemicals. 
Adult pathology can suggest the biological action mechanism of shear stress.

\section{PATHOLOGIC CALCIFICATION AND OSSIFICATION CAN BE INDUCED BY HYPOXIA AND ALKALOSIS}

Circumstantial evidence suggests that hypoxia and/or alkalosis also play a key role in pathologic calcification and ossification.

Cardiac ligature, subcutaneous implantation of glass diaphragms or exposure of a transplanted tendon to anoxia result in a transient chondrogenesis followed by enchondral ossification (49).

Similarly, Busher et al. (50) report the case of a patient who underwent gastric tube reconstruction. Following cardiac arrhythmia, he developed hypoxia and ischaemic necrosis over $5 \mathrm{~cm}$ of the proximal gastric tube. Three weeks later that area was ossified; trabecular bone was present along the entire length of the constricted gastric tube.

Ectopic ossification has been associated with several conditions in both neoplastic and not neoplastic tissue (50-53). Paraplegic patients frequently develop ectopic ossification $(50,54)$. But there is no significant difference of ectopic bone formation between paraplegic rabbits and non-paraplegic rabbits under the same immobilization and passive movement of the posterior legs. For Izumi (54), the reason may simply be poor oxygenation because of blood stasis.

Calcium mineral deposition in the atherosclerotic plaque results, also, from hypoxia. The vascular cell, when exposed to hydrogen peroxide, differentiates into an osteoblastic cell (55) this effect was counteracted by anti oxydants. Oxidative stress modulates the differentiation of bone and vascular cells oppositely (55).

Metabolic acidosis increases calcium efflux from bone and hypercalciuria (56). Metabolic acidosis increases osteoposis and osteomalacia, and propensity to develop kidney stones (57).By contrast, alkalosis neutralize endogenous acid production and improve bone mineral accretion $(56,58)$.

Calciphylaxis is a rapidly developing fatal process of vascular calcium deposition with prominent cutaneous manifestation. Metastatic pulmonary deposition is a complication of renal failure. The pathologic deposition of calcium is favored by alcalosis $(59,60)$.

\section{SHEAR STRESS AND PRESSURE MODIFY THE EXTRACELLULAR MATRIX AND CHANGE THE AVAILABILITY OF NUTRIENTS AND OXYGEN}

How shear stress and pressure may induce cell differentiation is a matter of speculation. It may be a direct effect, the release of a differentiation factor (61) or decreased availability of oxygen because of limited diffusion due to increased extracellular matrix.

Collagen is a vital component of the extracellular matrix of both muscles and tendons (62). It acts as a scaffold to maintain muscle shape and permit an even distribution of force, and plays a crucial role in the mechanical properties of the tendons. Under normal circumstances, collagen is continually being synthesized and degraded throughout life. Increased mechanical stress, which causes muscle hypertrophy stimulates collagen synthesis.The concentration of other extracellular molecules (laminin, fibronectin, vitronectin, etc.) is also modulated by mechanical stress (63).

Mechanical compression and tension generated by the condensing mesenchyme in the limb-bud (64) appears to be enough to constrict and close off the thinwalled undifferentiated blood vessels caught in the condensation foci (64), thus leading to avascular areas. The differentiation of muscle and cartilage has been interpreted in terms of vascular pre-pattern. Extracellular matrix and/or low oxygen tension differentiates stem cells into chondrocytes (65). Cartilage is practically avascular (nutrients are transported from the synovial fluid and vascularized subchondral bone) (66). Oxygen tensions within cartilage are therefore significantly lower than vascularized tissues ranging from 2.7 to $7.5 \%$ oxygen (66-68). In Vivo, pregnant mice are exposed to hypobaric oxygen. The embryos suffer from major scoliosis. The malformations are present in the cartilaginous stage of development of the vertebral column (69).

The effects of oxygen on cell differentiation are confirmed in vitro. Oxidative stress regulates cell function and proliferation (70). Low oxygen tension promotes and induces redifferentiation of dedifferentiated bovine articular chondrocytes (71).

\section{HYPOTHESIS: SHEAR STRESS INDUCES ALKALOSIS WHICH IS KNOWN TO INCREASE CALCIUM DEPOSITION}

Stylophora pistillata is a scleractinian coral. Its calcification is a function of mechanisms which concentrate the $\mathrm{CO}_{2}$ in coral cells (72). Pancreatites stones, a frequent complication of chronic pancreatitis are made of calcite $\left(\mathrm{CaCO}_{3}\right)$. The precipitation of $\mathrm{CaCO}_{3}$ is a function of the $\mathrm{pH}$ and the availability of bicarbonates (73). Similarly, extracellular alkalosis increases the calcium precipitation at the periphery of pancreatic $\mathrm{B}$ cells (74).

The $\mathrm{pH}$ surrounding the osteoclast is highly acidic (75). The apical bone-resorbing compartment of the osteoclast is sealed off by the attachment of the osteoclast 
to the calcified matrix and is actively acidified by the osteoclast. In the low pH environment of the bone-resorbing lacuna produced by the osteoclast, the mineral phase dissolves, exposing the organic matrix to the action of the secreted enzymes. These observations are consistent with a scheme in which, in the low pH environment of the bone-resorbing lacuna produced by the osteoclast, the mineral phase dissolves, exposing the organic matrix to the action of the secreted enzymes. The activity of these enzymes is in turn presumably favored by the acidic milieu. All constituents of the matrix, whether mineral or organic, then would be reduced to their elemental forms (ions and amino acids) extracellularly.

The secretion of acid by proton pumps involves cation-independent mannose-6-phosphate receptors. These receptors bind to an enzyme-linked mannose-6phosphate (75). There is 'in vitro' evidence of the importance of $\mathrm{pH}$ in bone formation and resorpsion. Metabolic acidosis increases urinary calcium excretion (58). By contrast, alkalosis neutralizes endogenous acid production and improves bone mineral accretion (58). Alkalosis causes a decrease in osteoclastic $\beta$-glucuronidase release, an increase in osteoblastic collagen synthesis and calcium deposition on the bone cells (76).

The link between hypoxia, alkalosis and calcium precipitation is complex and beyond the reach of this paper. Chemical hypoxia induces hypocapnia alkalosis in primary culture (77). Similarly, ischaemia and hypoxia may induce alterations of ion homeostasis, including alkalosis (78). Hexokinase transforms mannose into mannose-6-phosphate. This key enzyme is known to be regulated by hypoxia (79-81).

\section{CONCLUSION}

Currently, the predominant hypothesis explains cellular differentiation as an essentially genetic intracellular process. However, it is possible or even probable, that this differentiation is the result of simple biochemical and physical events of extracellular events origin.

The loss of cellular polarity is enough to explain the cancer shape, the shift from the branchial dichotomus structure of normal glands to the invasive dendritic nature of cancer $(32,82)$. The carcinogenic process is associated with a loss of cellular differentiation $(32,82)$.This dedifferentiation can be reversed (82-84).

It is possible that this dedifferentiation is simply due to a change in the cell's physico-chemical environment. The importance of the extracellular milieu could also explain how a tumor cell reinjected into a healthy blastocyst (84) or tissue (83), exposed to a normal environment can differentiate normally.

\section{ACKNOWLEDGEMENTS}

We want to acknowledge the constant help and advices of J. Leibowitch.

\section{REFERENCES}

1. Graham C. B. Assessment of bone maturation-methods and pitfall. Radiol Clin North Am 1972; 10: 185-202.

2. Cancedda R., Castagnola P., Cancedda F. D., Dozin B., Quarto R. Development control of chondrogenesis and osteogenesis. Int J Dev Biol 2000; 44: 707-714.

3. Sutphen J. L. Growth as a measure of the nutritional status. $J$ Pediatr Gastroenterol Nutr 1985; 4: 169-181.

4. Ubelaker D. H. Estimating age of death from immature human skeletons: an overview. J Forensic Sci 1987; 32: 1254-1263.

5. Kardon G. Muscle and tendon morphogenesis in the avian hind limb. Development 1998; 125: 4019-4032.

6. Burger E. H., Klein-Nulend J., Veldhuizen J. P. Modulation of osteogenesis in fetal rudiments by mechanical stress. $J$ Biomech 1991; 24: 101-109.

7. Carter D. R., Wong M., Orr T. E. Musculoskeletal ontogeny, phylogeny, and functional adaptation. J Biomech 1991; 24(S1): 3-16.

8. Turner C., Pavalko F. Mechanotransduction and functional response of the skeleton to physical stress: the mechanism and mechanics of bone adaptation. J Orthop Sci 1998; 3: 346-355.

9. Miura T. Congenital hand anomalies, and their association with other congenital abnormalities. Hand 1981; 13 267-270.

10. Stanescu V., Stanescu R., Maroteaux P. Pathogenic mechanisms in osteochondrodysplasia. J Bone Joint Surg Am 1984; 66: 817-836.

11. Hall B. K. Intracellular and extracellular control of the differentiation of cartilage and bone. Histochem 1981; 13: 599-614.

12. Matsui Y., Kawabata H., Ozono K., Yasui N. Skeletal develpment of achondroplasia. Pediatr Int 2001; 43: 361-363.

13. Roberts A., Evans G. A. Orthopedic aspects of neuromuscular disease in children. Curr Opin Pediatr 1993; 5: $379-383$

14. Opperman L. A., Drake D. B., Kang P., Nakeeb S. M., Gammas M., Morgan R. F. A pilot study of short and long term sequelae to rigid fixation across metaphyseal physes in a baboon model. Ann Plast Surg 2000; 44: 36-43.

15. Roebuck D. J. Skeletal complications in paediatric oncology. Radiographics 1999; 19: 873-885.

16. Schiessl H., Frost H. M., Jee W. S. Estrogen and bone-muscle strength and mass relationships. Bone 1998; 22: 1-6.

17. Backman E. Methods for measurement of muscle function. Methodological aspects, reference values for children, and clinical applications. Scand J Rehabil Med Suppl 1988; 20: 9-95.

18. Soliman A. T., Khadir M. M., Asfour M. Testosterone treatment in adolescent boys with constitutional delay of growth. Metabolism 1995; 44: 1013-1015.

19. Caine D., Lewis R., O'Connor P., Howe W., Bass S. Does gymnastics training inhibit growth of females. Clin J Sport Med 2001; 11: 260-270.

20. Wawryniak G. Biological age in children who practise swimming. Anthropol Anz 2001; 59: 149-156. 
21. Abad V., Uyeda J. A., Temple H. T., De Luca F., Baron J. Determinants of spatial polarity in the growth plate. Endocrinology 1999; 140: 958-962.

22. Goldspink G. Changes in muscle mass and phenotype and the expression of autocrine and systemic growth factors by muscle in response to stretch and overload. J Anat 1999; 194: 323-334.

23. Maganaris C. N. Load-elongation characteristics of in vivo human tendon and aponeurosis. J Exp Biol 2000; 203: 751-756.

24. Breen E. C., Fu Z., Normand H. Calcyclin gene expression is increased by mechanical strain in fibroblasts. Am J Respir Cell Mol Biol 1999; 21: 746-752.

25. Wilhelmi B. J., Blackwell S. J., Mancoll J. S., Phillips L. G. Creep vs. stretch: a review of the viscoelastic properties of skin. Ann Plast Surg 1998; 41: 215-219.

26. Hall G. D., Van Way C. W., Kung F. T., Compton-Allen M. Peripheral nerve elongation with tissue expansion techniques. J Trauma 1993; 34: 401-405.

27. Davies P. F., Tripathi S. C. Mechanical stress mechanisms and the cell. Circ Res 1993; 72: 239-245.

28. Fleury V., Schwartz L. D.L.A. from shear stress as a simple model of vasculogenesis. Fractals 1999; 7: 33-39.

29. Liu M., Xu J., Transwell A. K., Post M. Inhibition of mechanical strain-induced fetal rat lung cell proliferation by gadolinium, a stretch-activated channel blocker. J Cell Physiol 1994; 161: 501-507.

30. Murnin M., Kumar A., Li G., Brown M., Sumpio B. E., Basson M. D. Effects of glutamine isomers on human (Caco-2) intestinal epithelial proliferation, strain responsiveness and deformation. J Gastrointes Surg 2000; 4: 435-442.

31. Sonnenschein C., Soto A. Somatic mutation theory of carcinogenesis. Why it should be dropped and replaced? Mol Carcinogen 2000; 29: 1-7.

32. Fleury V, Schwartz L. Numerical investigation of loss of cellular polarity on squamous cell carcinoma invasivness and geometry. Fractals (in print).

33. Wong M., Carter D. R. Theoretical stress analysis of organ culture osteogenesis. Bone 1990; 11: 127-131.

34. Tanck E., Van Driel W. D., Hagen J. W., Burger E. H., Blankevoort L., Huiskes R. Why does intermittent hydrostatic pressure enhance the mineralization process in fetal cartilage? J Biomech 1999; 32: 153.

35. Burger E., Klein-Nulend J., Veldhuuzeen J. P. Modulation of osteogenesis in fetal bone rudiments by mechanical stress in vitro. J Biomech 1991; 24: 101-109.

36. Maitournam H, Chassignet $P$, Halphen B, Schwartz L. Shear stress and ossification. C R Acad Sci (Paris) (submitted).

37. Shi-Jun L., Wei-Dong L., Rui-Xue M., En-Guang K. Morphometric study on development of fetal hip. Chin Med $J$ 1998; 101: 750-754.

38. Caterson EJ, Nesti LJ, Albert T, Danielson K, Tuan R. Application of mesenchymal stem cells in the regeneration of musculoskeletal tissue. Med Gen Med 2001; Feb5: E1.

39. Swartz M. A., Tschumperlin D. J., Kamm R. D., Drazen J. M. Mechanical stress is communicated between different celle types to elicit matrix remodelling. PNAS 2001; 98: 6180-6185.

40. Bard J. Morphogenesis. UK: Cambridge University Press, 1990.

41. Oster G. F., Murray J. D., Harris A. K. A model for chondrogenic condensations in the developing limb: the role of extracellular matrix and cell tractions. J Embryol Exp Morph 1985; 89: 93-112.
42. Googdman S., Aspenberg P. Effects of mechanical stimulation on the differentiation of hard tissue. Biomaterials 1993; 14: 563-568.

43. Carter D. R., Beaupre G. S., Giori N. J., Helms J. A. Mechanobiology of skeletal regeneration. Clin Orthop $S$ 1998; 355: 41-55.

44. Jim M., Franck E. H., Quinn T. M., Hunziker E. B., Grodzinsky A. J. Tissue shear deformation stimulates proteoglycan and protein biosynthesis in bovine cartilage explants. Arch Biochem Biophys 2001; 395: 41-48.

45. Smith R. L., Donlon B. S., Gupta M. K., Mohtai M., Das P., Carter D. R., Cooke J., Gibbons G., Hutchinson N., Schurman D. J. Effects of fluid induced shear stress on articular chondrocytes morphology and metabolism in vitro. J Orthop Res 1995; 13: 824-831.

46. Brand R. A., Stanford C. M., Nicolella D. P. Primary adult bone cells do not respond to tissue (continuum) level strains. J Orthop Sci 2001; 6: 295-301.

47. Sadoshima J., Izumo S. The cellular and molecular response of cardiac myocytes to mechanical stress. Annu Rev Physiol 1997; 59: 551-571.

48. Harris A. K., Stopak D., Wild P. Fibroblast traction as a mechanism for collagen morphogenesis. Nature 1981; 290: 249-251.

49. Danis A. Soft tissue ossification: mechanism. Bull Mem Acad $R$ Belg 1992; 147: 298-306.

50. Buscher H. C., Van Lanschot J. J., Mulder A. H., Tilanus H. W. Heterotopic ossification induced by hypoxia in a retrosternal gastric tube following transhiatal Oesophagectomy. J Clin Pathol 1995; 48: 177-178.

51. Ackerman N. B. Bone formation in the gastric mucosa following subtotal gastrectomy in rats. Exp Mol Pathol 1968; 9: $125-130$.

52. An H. S., Ebrahem N., Kim K., Jackson W. T., Kane J. T. Heterotopic ossification and pseudoarthrosis in the shoulder following encephalitis. Clin Orthop 1987; 219: 291-298.

53. Asa D. K., Bertorini T. E., Pinals R. S. Myositis ossificans circumscripta: a complication of tetanus. Am J Med Sci 1986; 292: 40-43.

54. Izumi K. Study of ectopic bone formation in experimental spinal cord injured rabbits. Paraplegia 1983; 21: 351-363.

55. Mody N., Parhami F., Sarafian T. A., Demer L. L. Oxydative stress modulates differentiation of vascular and bone cells. Free Rad Biol Med 2001; 31: 509-519.

56. Bushinsky D. A., Krieger N. S., Geisser D. I., Grossman E. B., Coe F. L. Effects of $\mathrm{pH}$ on bone calcium and protons flux in vitro. Am J Physiol 1983; 245: 204-209.

57. Wiederkehr M., Krapf R. Metabolic and endocrine effects of metabolic acidosis in human. Swiss Med Wkly 2001; 131: 127-132.

58. Bushinsky D. A. Metabolic alkalosis decreases bone calcium efflux by suppressing osteoclasts and stimulating osteoblasts. Am J Physiol 1996; 271: 216-222.

59. Matsuo T., Tsukamoto Y., Tamura M., Hanakoa M., Nagaoka T., Kobayashi Y., Higashiara M., Yokoyama H., Saegusa N. Acute respiratory failure to "pulmonary calciphylaxis" in a maintenance haemodialysis patient. Nephron 2001; 87: 75-79.

60. Bloodworth J., Tomashefski J. F. Localised pulmonary metastatic calcification associated with pulmonary artery obstruction. Thorax 1992; 47: 174-178.

61. Jin M., Frank E. H., Quinn T. M., Hunziker E. B., Grodzinsky A. J. Tissue shear deformation stimulates proteoglycan and 
protein biosynthesis in bovine cartilage explants. Arch Biochem Biophys 2001; 395: 41-48.

62. Bishop J. E. Regulation of cardiovascular collagen deposition by mechanical forces. Mol Med Today 1998; 4: 69-75.

63. Loeser R. F. Chondrocyte integrin expression and function. Biorheology 2000; 37: 109-116.

64. Wilson D. J. Development of avascularity during cartilage differentiation in the embryonic limb. Differentiation 1986; 30: $183-187$.

65. Von Der Mark K., Conrad G. Cartilage and cell differentiation:a review. Clin Orthop 1979; 139: 185-205.

66. Murphy C., Sambanis A. Effect of oxygen tension on chondrocyte extracellular matrix accumulation. Connective Tissue Res 2001; 42: 87-96.

67. Brighton C. T., Heppenstall R. B. Oxygen tension in zone of the epiphyseal plate the metaphysis and the diaphysis. Am J Bone Joint Surg 1971; 53: 719-728.

68. Ellis S., Velayutham M., Velan S., Petersen E., Zweiler J., Kuppusamy P., Spencer R. EPR oxygen mapping of engineered cartilage in reactor grown in a hollow-fiber bioreactor. Mag Res Med 2001; 46: 819-826.

69. Rivard C. H., Labelle P., Simoneau R., Duhaime M., Poitras B., Simard P. Moderate hypobaric hypoxia used as an inducer of congenital vertebral malformation in mouse's embryo. Chir Pediatr 1982; 23: 65-67.

70. Butler A. J., Eagleton M. J., Wang D., Howell R. L., Strauch A. R., Khasgiwala V., Smith H. C. Induction of the proliferative phenotype in differentiated myogenic cells by hypoxia. $J$ Biol Chem 1991; 266: 18250-18258.

71. Domm C., Schunke M., Christesen K., Kurz B. Redifferentiation of dedifferentiated bovine articular chondrocytes in alginate culture under low oxygen tension. Osteoarthritis Cartilage 2002; 10: 13-22.

72. Furla P., Galgani I., Durand I., Allemand D. Sources and mechanisms of inorganic carbon transport for coral calcification and photosynthesis. J Exp Biol 2000; 203: 3445-3457.

73. Moore E. W., Verine H. J. Pancreatic calcification:formation constants of $\mathrm{CaHCO}^{3+}$ and $\mathrm{CaCO} 3$ (0) complexes determined with $\mathrm{Ca}^{2+}$ electrodes. Am J Physiol 1981; 241: G182-G190.
74. Rebolledo O. R., Semino M. C., Gaglardino J. J. Effect of extracellular alkalosis upon calcium distribution within B cells. Acta Physiol Latinoam 1988; 38: 329-343.

75. Baron R. Molecular mechanisms of bone resorption by the osteoclast. Anat Rec 1989; 224(2): 317-324.

76. Carano A., Schlesinger P. H., Athanasou N. A., Teitelbaum S. L., Blair H. C. Acid and base effects on avian osteoclast activity. Am J Physiol 1993; 264: 694-701.

77. Jorgensen N. K., Petersen S. F., Damgaard I., Shousboe A., Hoffmann E. K. Increase in $\mathrm{Ca}^{2+}$ and changes in intracellular $\mathrm{pH}$ during chemical anoxia in mouse neocortical neurons in primary culture. J Neurosci Res 1999; 56: 358-370.

78. Katsura K., Ekholm A., Siesjo B. K. Coupling among changes in energy metabolism, acid-base homeostasis and ion fluxes in ischaemia. Can J Physiol Pharmacol 1992; 70: S170-S175.

79. Yoon D. Y., Buchler P., Saarikoski S. T., Hines O. J., Reber H. A., Hankinson O. Identification of genes differentially induced by hypoxia in pancreatic cancer cells. Biochem Biophys Res Commun 2001; 288: 882-886.

80. Riddle S. R., Ahmad A., Ahmad S., Deeb S. S., Malkki M., Schneider B. K., Allen C. B., White C. W. Hypoxia induces hexokinase II gene expression in human lung cell line A549. Am J Physiol Lung Cell Mol Physiol 2000; 278: 407-416.

81. Niitsu Y., Hori O., Yamaguchi A., Bando Y., Ozawa K., Tamatani M., Ogawa S., Tohyama M. Exposure of cultured primary rat astrocytes to hypoxia results in intracellular glucose depletion and induction of glycolytic enzymes. Brain Res Mol Brain Res 1999; 74: 26-34.

82. Schwartz L., Balosso J., Baillet F., Brun B., Amann J. P., Sasco A. J. Cancer, the role of extracellular disease. Med Hypothesis 2002; 58: 340-346.

83. Coleman W., Wennerberg A. E., Smith G. J., Grisham J. W. Regulation of the differentiation of diploid and aneuploid rat liver epithelial cells by the liver microenvironment. Am J Pathol 1997; 142: 1373-1382.

84. Illmensee K., Mintz B. Totipotency and normal differentiation of single teratocarcinoma cell cloned by injection into blastocysts. Proc Natl Acad Sci USA 1976; 73 : 549-553. 